日消外会誌 32 ( 9 ) : 2224 2230, 1999年

原 著

\title{
大腸腺腫の悪性化過程におけるアポトーシス関連蛋白の 影響に関する免疫組織学的検討
}

\author{
岐阜大学医学部第 2 外科 \\ 堅田昌弘杉山 保幸国枝克行佐治 重豊
}

大腸腺管腺腫174病変を対象に変異型 p53と BCl-2の発現,T UNEL 染色による A I 值を免疫組織学的 に検討した . 谷の結果, Bcl-2陽性率は異型度か軽度から中等度に進行すると有意に増加し，高度およ び早期癌では逆に低下した .変異型 p53陽性率は異型度の進行に伴って増加し, 早期癌ではさらに高値 を示した．AI值は正常粘膜に比べ軽度群，中等度群，高度群および早期癌がいずれも低值を示した． 変異型 p53と Bcl-2陽性率は腺腫径では6mm 以上, 形態ではI sp, I p 型が有意の高値を示した .

以上の結果，1)腺腫の増大や異型度の早期には Bcl-2が, 癌化の段階には変異型 p53か関与する可能 性が示唆された．2) 異型度が中等度以上で大きさが $6 \mathrm{~mm}$ を越える有茎性腺腫は, 生物学的悪性度が 高いと推察された .

Key words : colorectal adenoma, mutant $\mathrm{p} 53, \mathrm{Bcl}-2$ protein, T UNEL stain, apoptosis

はじめに

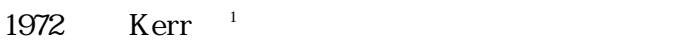
て以来, 発癌過程のイニシェーションからプロモー ション段階での，アポトーシス制御機構の乱れが注目 されており $)^{2)}$ ，またアポトーシス実行段階では, 癌抑制 遺伝子 p53か情報処理過程で主要な役割を演ずると考 えられている゙ .すなわち，V ogelstein ら"が大腸癌の 多段階発癌過程の遺伝子変異モデルを提唱して以来， 大腸腺腫の悪性化過程で p53遺伝子変異が高頻度に検 出されることが確認されている゙5). 弚こで 著者らも内 視鏡的に摘除した大腸腺腫を用い, proliferating cell nuclear antigen (以下, PCNA ) ${ }^{6}$ と変異型 p53蛋白 (以

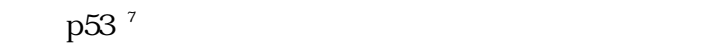
果, 異型度の進展に伴いPCNA の labeling index（以 下，LI）とp53の発現が有意に増加し，アポトーシスの 関与が示唆され先に報告した ${ }^{8)}$. 乥こで今回同じ症例 を用い, Bcl-2蛋白 ${ }^{9)}$ の発現程度から悪性化過程におけ るアポトーシスの役割を検索し，TdT-mediated dUT P-biotin nickend labeling (以下, T UNEL) 染色 ${ }^{10)}$ による apoptotic index (以下，AI) から細胞死実行程 度を評価した。また，先に報告路したp53の発現程度も 併せて検討し , 大腸腺腫の悪性化過程におけるアポ

<1999年 4 月28日受理 > 別刷請求先 : 堅田 昌弘

干 501-8076 岐阜市司町40 岐阜大学第 2 外科
トーシスの役割を検討した 。

対象と方法

\section{1. 対象}

対象は1992年 1月から 4年間に教室および関連病院 で,内視鏡的に摘除した大腸腺管腺腫109例，174病変 である．なお，同期間に内視鏡的に摘除した癌が粘膜 内にとどまり，粘膜下層に及んでいない早期大腸癌10 例，10病变と，大腸癌手術時に採取した大腸正常粘膜 組織10例，16個を対象群として用いた。

\section{2. 方法}

1) 組織標本の作製法

摘除検体を $10 \%$ ホルマリン固定パラフィン包埋後， 4 $\mu \mathrm{m}$ の連続薄層切片を作製し通常の Hematoxylin Eo$\sin$ (以下, HE) 染色と免疫組織染色用に供した。

2) 大腸腺腫の異型度と大きさの評価法

細胞異型度は, HE 染色標本を用い大腸癌取扱い規 約 ${ }^{111}$ に従って, 軽度異型腺腫 (以下, 軽度群)，中等度 異型腺腫 (以下，中等度群)，高度異型腺腫 (以下，高 度群) および早期癌に分類した . 大きさは，内視鏡所 見から最大径で $6 \mathrm{~mm}$ 未満を小，6から $10 \mathrm{~mm}$ 未満を 中，10mm 以上を大と分類した。

3) 免疫組織染色の方法

Bcl-2染色 : キシレンにて脱パラフィン・親水処理 後,マイクロウェーブ処理し抗 Bcl-2マウスモノクロー ナル抗体 (clone124, D A KO 社)を用い avidine-biotiny I- 
Fig. 1 Positive expression of $\mathrm{Bcl}-2$ (a) and T UNEL (b) by immunohistochemical stain $(\times 200)$

a) $\mathrm{Bcl}-2$

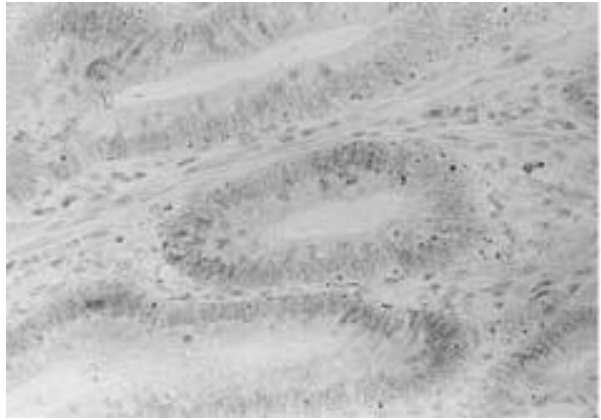

b) T UNEL

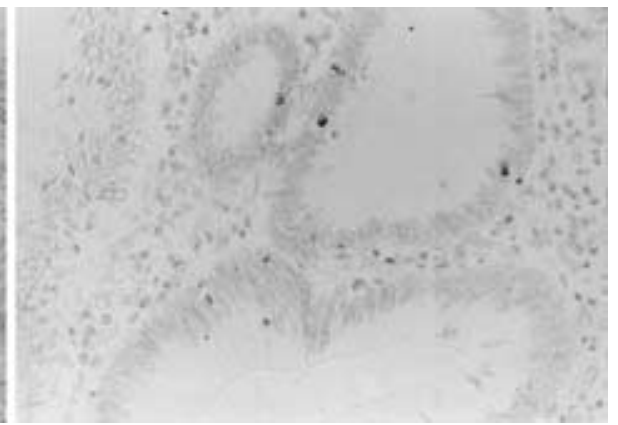

Table 1 Comparison on positive expressin of $\mathrm{Bcl}-2$ and mutant p53, and value of apoptotic index (A I) evaluated by TUNEL stain according to the grade of histological aty pia of colorectal adenoma

\begin{tabular}{|c|c|c|c|}
\hline & Bc1-2(\%) & value of A I & p53(\% ) \\
\hline normal & $\mathrm{O}(0) \quad$ a) & $\left.4.70 \pm 8.20^{f}\right)$ & $O(0) \quad k)$ \\
\hline mild & $7(19.4)^{\mathrm{b})}$ & $0.98 \pm 1.289)$ & $O(0) \quad 1)$ \\
\hline moder ate (94) & $48(51.1)^{c)}$ & $1.50 \pm 2.34^{h)}$ & $\left.29(30.9)^{m}\right)$ \\
\hline severe & $23(52.3)^{d)}$ & $\left.1.91 \pm 2.30^{i}\right)$ & $22(50.0)^{n)}$ \\
\hline cancer & $\left.4(40.0)^{\mathrm{e}}\right)$ & $1.65 \pm 0.89$ ) & $\left.80(80.0)^{0}\right)$ \\
\hline
\end{tabular}

(n) $\quad($ mean \pm SD)

a)—c) $: p=0.001$, a)—d) $: p=0.002$, a)—e) $: p=0.04$,

b)—c) $: p=0.001, b)-d): p=0.002, f)-g), f)-h$ ),

f)—i) , p = 0.0001, f)—j) : p <0.01,k)—n ), k)—o), l)

$(-\mathrm{m}),(\mathrm{l}-\mathrm{n}), \mathrm{I})-0): \mathrm{p}<0.0001, \mathrm{~m})-\mathrm{n}): \mathrm{p}=0.02$,

m) - $): p=0.004$

あった . 大きさは小が83病変, 中が56病変, 大が35病 変で, 形態分類上は I s が30病変, I sp が98病変, I p が46病変であった . 占居部位では, 盲腸が 2 例, 上行 結腸が22例，横行結腸が25例，下行結腸が13例，S状結 腸が72例，直腸が40例であった . なお，併存病変で早 期大腸癌が 2 例 5 病変, 進行大腸癌が 9 例14病変にみ られた . 一方 , 対象群の早期癌10例はいずれも高分化 腺癌で, 腫瘍径は 6 から $50 \mathrm{~mm}$, 平均 $14.5 \pm 12.9 \mathrm{~mm}$,中 が 4例，大が 6 例であった . 早期癌の形態は de novo 発生を示唆する表面型や宿没型はなく , I sp が 4 例 , I $\mathrm{p}$ が6例にみられた . 占居部位は下行結腸が 2 例， $\mathrm{s}$ 状結腸が 5 例，直腸が 3 例であった ${ }^{8)}$.

2 . 免疫組織染色所見の結果

1) 細胞異型度との関連

$\mathrm{BCl}-2$ 陽性率は正常粘膜と軽度群から，中等度群，高 度群と増加したが , 中等度群と高度群との間に差はみ 
Table 2 Comparison on positive expression of $\mathrm{Bcl}-2$ and mutant $\mathrm{p} 53$, and value of apoptotic index (AI) evaluated by TUNEL stain according to the clinico-pathological findings of patients with colorectal adenoma

\begin{tabular}{|c|c|c|c|c|}
\hline & & $\mathrm{Bcl}-2(\%)$ & value of A I & p53(\%) \\
\hline \multirow[t]{3}{*}{ T umor size } & $2-5 \mathrm{~mm}$ & $29(34.9)$ a) & $1.40 \pm 2.55$ & $11(13.3)^{c)}$ \\
\hline & $6-9 \mathrm{~mm}$ & $31(55.4)$ b) & $1.48 \pm 1.91$ & $27(48.2) d$ \\
\hline & $10 \mathrm{~mm} \leqq$ & $18(51.4)$ & $1.74 \pm 1.48$ & $13(37.1)$ e) \\
\hline \multirow[t]{3}{*}{ subty pe } & Is & $8(26.7)^{f)}$ & $1.74 \pm 3.73$ & $2(6.7)^{h}$ \\
\hline & Isp & $\left.48(49.0)^{g}\right)$ & $1.25 \pm 1.34$ & $29(29.6)$ i) \\
\hline & Ip & $22(47.8)$ & $1.87 \pm 2.22$ & $20(43.5)^{j l}$ \\
\hline \multicolumn{5}{|c|}{ number of adenoma } \\
\hline & $1-3$ & $69(50.0) \mathrm{k})$ & $1.49 \pm 2.06$ & $42(30.4)$ \\
\hline & $4 \leqq$ & $9(25.0)^{1)}$ & $1.54 \pm 2.58$ & $9(25.0)$ \\
\hline \multirow{2}{*}{\multicolumn{2}{|c|}{$\begin{array}{l}\text { with cancer } \\
\text { without }\end{array}$}} & $3(15.8) \mathrm{m})$ & $2.26 \pm 4.56$ & $4(21.1)$ \\
\hline & & $75(48.4)^{n)}$ & $1.40 \pm 1.66$ & $47(30.3)$ \\
\hline
\end{tabular}

$($ mean $\pm \mathrm{SD})$

a)—b) $: p=0.01, c)-d): p<0.0001, c)-e): p=0.003, f)-g): p=0.02$, h) -

i) $: p=0.007, h)-j): p=0.0004, k)-1): p=0.04, m)-n): p=0.01$

られず，早期癌では逆に低値を示した．

A I 值は正常粘膜に比べ軽度群, 中等度群, 高度群お よび早期癌がいずれも低值を示した．

p53陽性率は正常粘膜と軽度群がともに陰性で, 中 等度群 , 高度群 , 早期癌の順に増加し, 中等度群と高 度群および早期癌との間に有意差がみられた (Table 1) .

2) 臨床病理学的所見との関連

大きさ別検討で Bcl-2陽性率は，小が34.9\% ,中が55.4 \% ,大が51.4\%で,中は小に比べて有意の高值を示した が ,中と大との間に差はみられなかった . A I 值は小か ら中，大へと増加したが有意差はみられなかった . p 53陽性率は中および大は小に比べ有意の高值を示した が , 中と大との間に差はみられなかった .

形態別検討では Bcl-2p昜性率は，I sp がl s に比べ有 意の高値を示し ,AI 值は各群間で差はみられなかった が , p53陽性率は I s, I sp, I p の順に増加し，I s と I sp およびIsと I p との間に有意差がみられた .

病変数別では Bcl-2陽性率は 3 個以下群で有意の高 值を示したが, p53陽性率と AI 值は両群間で差がみら れなかった 。

癌併存例の Bcl-2陽性率は非併存例に比べ有意の低 値を示したが , A I 值と p53陽性率に差はみられなかっ た (Table 2).

3) 変異型 $\mathrm{p} 53$ Bcl-2発現程度との関連

平均腫瘍径は p53と Bcl-2がともに陽性群が，ともに
Fig. 2 Cut off value on positive rate of mutant p53 and $\mathrm{Bcl}-2$ accoring to tumor size by receiver operating char acteristic curve

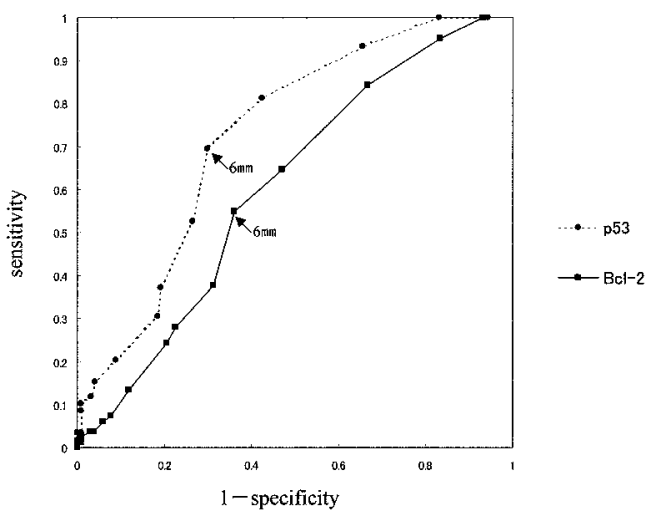

陰性群に比べ有意の高値を示した .一方，大きさ別に p53と Bcl-2の陽性率を receiver oper ating char acterisitic (ROC) 曲線 ${ }^{122}$ で検討すると， cut-off 值はともに $6 \mathrm{~mm}$ となった(Fig. 2). 光こで, $6 \mathrm{~mm}$ 以上群と末満群 に分け検討すると，ともに陽性となる頻度は，6mm 以上群が $6 \mathrm{~mm}$ 未満群に比べ有意に高かった 細胞異型 度別では, 軽度群と中等度群, 高度群, 早期癌の間に 有意差を認めた(Table 3-a) . 一方，ともに陰性群は6 $\mathrm{mm}$ 以上群が末満群に比べ有意の低值を示し, 細胞異 型度別では，正常粘膜および軽度群と中等度群以上と の間に有意差がみられた .なお，ともに陽性群はとも 
Table 3 Significance of colorectal adenoma showing both positive or negative expression (\%) of mutant p53 and Bcl-2 protein (mean \pm SD)

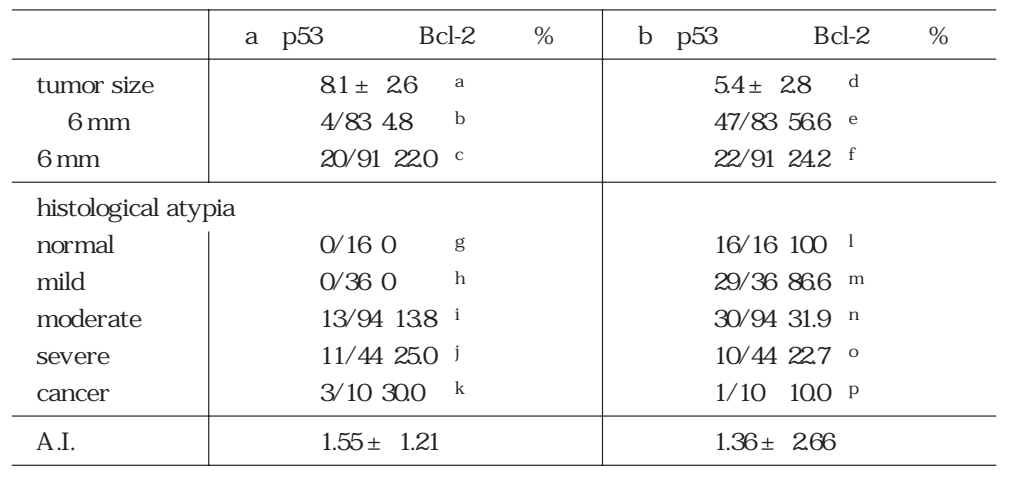

$($ mean $\pm \mathrm{SD})$

a)—d) , b)-c), e)—f) $: p<0.001$, h) - i) $: p=0.04, h)-j): p=0.004, h)-$

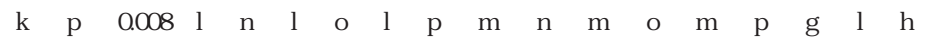
m) $:$ p $<0.001$, i - n) $: p=0.003$

Table 4 Significance of colorectal adenoma showing either positive or negative expression (\%) of mutant p53 and $\mathrm{Bcl}-2$ protein

\begin{tabular}{|c|c|c|}
\hline & a) $\mathrm{p} 53(+) \& \mathrm{Bcl}-2(-)(\%)$ & b) $\mathrm{p} 53(-) \& \mathrm{Bcl}-2(+)(\%)$ \\
\hline $\begin{array}{l}\text { tumor size } \\
<6 \mathrm{~mm} \\
6 \mathrm{~mm} \leqq\end{array}$ & $\begin{array}{l}8.2 \pm 5.0 \\
7 / 83(8.4) \text { a) } \\
20 / 91(22.0) \text { b) }\end{array}$ & $\begin{array}{l}6.74 \pm 3.0 \\
23 / 83(30.1) \\
29 / 91(31.9)\end{array}$ \\
\hline \multicolumn{3}{|c|}{ histological aty pia } \\
\hline normal & $0 / 16(0)$ & $0 / 16(0)$ \\
\hline mild & $0 / 36(0)$ & $7 / 36(19.4)$ \\
\hline moderate & $16 / 94(17.0)$ e) & $35 / 94(37.2) j)$ \\
\hline severe & $11 / 44(25.0) f)$ & $12 / 44(27.3)$ \\
\hline cancer & $5 / 10(30.0) \mathrm{g})$ & $1 / 10(10.0)$ \\
\hline A.I. & $1.89 \pm 2.76$ & $1.41 \pm 1.31$ \\
\hline
\end{tabular}

a)—b) : p < 0.01, c)—g) : p = 0.02, d)—e) $: p=0.004$, d)—g) $: p<0.0001$, e) -g) $: p=0.03$, h) -j) $: p=0.04$, d)—i) $: p=0.006, e)-j): p<0.001$

に陰性群に比べ異型度別の正常群，軽度群および中等 度群で低値を，AＩ值は軽度高值を示した(Table 3-b) 。

次に , p53かi陽性で Bcl-2力i陰性の場合は, $6 \mathrm{~mm}$ 以上 群は未満群に比べ高値を示した . 異型度別では, 異型 度の進行に伴って漸増し，正常粘膜と早期癌，軽度群 と中等度群 , 高度群および早期癌との間に有意差がみ られた(Table 4-a).一方,p53力陰性でBcl-2力陽性と なる場合は,6mm 以上群と未満群の間に差はみられな かった . 異型度別では, 正常粘膜から中等度群までは 増加し, 弚の後, 中等度群, 高度群から早期癌と逆に 減少し, 正常粘膜と中等度群との間に有意差がみられ た(Table 4-b) .なお,p53力陽性でBcl-2力陰性例は前
Table 5 The value apoptotic index according to positive or negative expression of $\mathrm{Bcl}-2$ and mutant p53

\begin{tabular}{l|c|c}
\hline & positive expression & negative expression \\
\hline Bcl-2 & $1.45 \pm 1.27$ & $1.53 \pm 2.69$ \\
p53 & $1.77 \pm 2.17$ & $1.38 \pm 2.17$ \\
\hline \multicolumn{2}{|c}{}
\end{tabular}

者が陰性で後者か陽性例に比べ, 平均腫瘍径で差はみ られなかったが, 異型度別で軽度群と中等度群は有意 差がみられた .なお，AI值は軽度高値であった .

4) AI 值と Bcl-2およびp53との関連 
A I 值は BCl-2陽性群が陰性群に比べ低値を示したが 有意差はみられなかった .また,p53陽性群は陰性群に 比べ高値を示したが有意差はみられなかった (Table 5) .

\section{考 察}

ヒト大腸の正常粘膜より腺腫を経ての悪性化過程 は, 家族性大腸腺腫症の原因遺伝子である A PC の不 活性化に始まる軽度異型腺腫から ,K-ras, p53などの点 突然変異を経て大腸癌へ進展し,DCC 異常が浸潤・転 移に関与する癌化のモデル4が知られている，一方，発 癌機構のイニシェーション過程で, 癌抑制遺伝子や DNA 修復遺伝子が効率的に機能すれば異常細胞のク ローナルな増殖が抑制され, 癌化へのステップが中断 されるが , この段階でアポトーシス制御メカニズムが 重要な役割を担うと推察されている ${ }^{13)}$. 光こで本研究 では, 大腸前癌病変である腺管腺腫を対象にp53と Bcl-2を免疫組織学的に検索し，悪性化過程におけるア ポトーシス関連蛋白の役割とアポトーシスの関係を解 明せんと試み，上記諸結果を得た，すなわち，野生型 p53は種々のストレスが細胞に加わった際にc-fosや c-mycなどの増殖・分化に関わる遺伝子を制御して， G1期から S 期への細胞周期移行を抑制し Bax の転写 を賦活することでアポトーシスを誘導し，異常細胞の 増殖を制御する機能が知られている ${ }^{14)}$.このp53の変 異・欠失はさまざまな癌腫で高頻度に確認され，癌抑 制遺伝子として理解されているが7変異型 p53の作用 は本来の機能喪失と野生型との複合体形成による機能 失活の両者が知られている ${ }^{15)}$. 弚れゆえ, 大腸癌の adenoma-car cinoma sequence で p53遺伝子異常が腺 腫から大腸癌への段階で重要な役割を演ずると考えら れており，今回の検索でも p53の陽性率は，正常粘膜と 軽度群でともに0\%であったが, 腺管腺腫異型度の進 行に伴って有意に増加し，早期癌ではさらに高值を示 したことから，同樣機序の存在か確認された .

一方, bcl-2遺伝子はヒト濾胞性 B 細胞リンパ腫付随 の $\mathrm{t}(14 ; 18)(\mathrm{q} 32 ; \mathrm{q} 21)$ 転座点の解析から単離された がん遺伝子で ${ }^{99} ， 3$ エソンからなり，分子量は26Kd で，核外膜，小胞体膜，ミトコンドリア膜など多くの 膜コンパートメントに存在し ${ }^{16)}$ ，アポトーシス抑制作 用を示すと考えられている ${ }^{17)}$.一般に，bcl-2遺伝子発 現は造血系やリンパ系に顕著であるが，小腸や大腸ク リプトの基底部でも観察され ${ }^{18)}$, 正常大腸粘膜，過形 成ポリープ, 腺腫, 癌腫での免疫組織学的検索で bcl2遺伝子異常が認められ, 発癌過程に関与する可能性が
Table 6 The values of PCNA LI according to positive or negative expression of $\mathrm{Bcl}-2$ and mutant p53(mean \pm SD)

a) value of PCNA

\begin{tabular}{l|c|c}
\hline & positive expression & negative expression \\
\hline Bcl-2 & $65.9 \pm 26.2^{\text {a) }}$ & $\left.48.3 \pm 30.0^{b}\right)$ \\
P53 & $62.7 \pm 27.8$ & $53.5 \pm 30.0$ \\
\hline
\end{tabular}

a)—b) : p $<0.0001$

(mean $\pm \mathrm{SD})$

b) apoptotic index according to low $\mathrm{LI}$ and high LI of PCNA

\begin{tabular}{l|l}
\hline high LI* & $1.57 \pm 1.82$ \\
low LI & $1.41 \pm 2.49$ \\
\hline
\end{tabular}

$\left({ }^{*}\right.$ high $\left.\mathrm{LI} \geqq 50\right) \quad($ mean $\pm \mathrm{SD})$

報告されている ${ }^{19)}$ ，今回の検討でも，Bcl-2陽性率は腺 管腺腫の異型度か軽度群から中等度群までは高値を示 し，弚の後中等度群から高度群，さらに早期癌で逆に 低值を示した .すなわち，Bcl-2は正常細胞が変異をき たす早期段階で関与する可能性が示唆されたわけであ

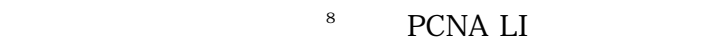
討すると，BCl-2陽性例は PCNA LI 值が有意の高値を 示し , PCNA LI 高值群ではAI 值が高值を示した(Table 6) .この結果は，発癌過程の早期段階では細胞増殖 能とアポトーシスによる細胞喪失がともに高く，この バランスで癌化への過程が抑制されていたが, 光の後 アポトーシス細胞が減少し早期癌へと進展する可能性 か確認された .また，变異型 p53は腺管腺腫の中等度異 型段階で発現し，弚の後有意に増加したことから腺腫 の増大や異型度の増加段階では bcl-2遺伝子の活性化 が優位で, 癌化の段階では p53遺伝子異常がアポトー シスによる細胞死回避を引き起こし，細胞不死化状態 に至ると推察された .

ところで，自験例での T UNEL 染色によるAＩ值で のアポトーシス実行程度は, 正常粘膜に比べ軽度群, 中等度群，高度群および早期癌がいずれも低值を示し た .この腺管腺腫の異型度と A I 值との関連は,相関あ りとする報告と ${ }^{20)}$ ，なしとする報告 ${ }^{21}$ があり，一定の 見解はみられていない．理由として，アポトーシスの 検索手段で形態学的方法と生化学的方法による差，高 度異型腺腫と癌化する腺腫が異なる可能性などが推察 される.また ,AI 值と p53あるいは Bcl-2の発現との間 に有意の関連はみられなかった．この結果は，細胞異 型度の進行段階で細胞増能が六進すると，2次的に $p$ 53以外の経路を介してアポトーシスが促進される可能 性が推察され，Clarke ら ${ }^{221}$ はp53を介さないアポトー 
シスの経路の存在を示しており，アポトーシス関連遺 伝子の発現とアポトーシス実行程度との間には複雑な 要因か関与するものと考えている .

ところで, 大腺癌切除後に発見される異時性腺腫に 対し家田ら ${ }^{23}$ は, 早期の過程から Bcl-2とp53か過剩発 現しており, 分子生物学的悪性度が高いと指摘してい る.著者らの癌併存例での検討で, Bcl-2陽性率は非併 存例に比べ逆に低值で, p53陽性率とも有意の関連は みられなかった . また , adenomarcarcinoma sequence に関連する腫瘍性病変の数でも，4個以上群は未満群 に比べ p53や Bcl-2の陽性率は有意に低值であった .光 れゆえ, 今回の検討結果からは, 癌に併存した腺腫や 多発腺腫でも分子生物学的悪性度は必ずしも高いとも いえず，癌化への可能性を規定する因子としての貢献 度は少ないと推察している。

以上の結果から，p53や Bcl-2蛋白の発現程度を免疫 組織学的に検索する意義は, 病理組織学的に細胞異型 度が中等度以上で, 大きさが $6 \mathrm{~mm}$ を越え, $\mathrm{sp}$ あるい はI p の形態を呈する例では, 細胞増殖能が六進する とともにアポトーシスも促進されるが, 弚の後アポ トーシスが抑制されて癌化へ進む可能性が推察され た。

\section{文 献}

1) Kerr JF, Wyllie AH, Currie AR : A poptosis : a basic biological phenomenon with wideranging implications in tissue kinetics. $\mathrm{Br} J$ Cancer 26 : 239-257, 1972

2) 田沼靖一: アポトーシス.東京大学出版会, 東京, 1994, p106-108

3）武藤徹一郎 : 大腸ポリープ・ポリポーシス . 医学 書院, 東京, 1993, p96-98

4) Fearon $E R, V$ ogelstein $B: A$ genetic model for colorectal tumorigenesis. Cell 61 : 759—777, 1990

5) Baker SJ, Fearon ER, Nigro JM et al : Chromosome 17 deletions and $\mathrm{p} 53$ gene mutations in color ectal carcinomas. Science 244 : 217-221, 1989

6) Miyachi K, Fritzler MJ, T an EM : A utoantibody to a nuclear antigen in prolifer ating cells. J Immunol 121 : 2228-2234, 1978

7) Nigro JM, Baker SJ, Presinger A C et al : Mutations in the p53 gene occur in diverse human tumor ty pes. Nature 342 : 705—708, 1989

8) 堅田昌弘，杉山保幸，国枝克行ほか : 大腸腺腫の悪 性化過程における細胞増殖能と変異型 p53蛋白発 現に関する免疫組織学的検討 : 日本大腸肛門病会 誌 $52: 16-22,1999$

9) $T$ sujimoto $Y, F$ inger $L R, Y$ unis $J$ et al : Cloning of the chromosome breakpoint of neoplastic B cells with the $\mathrm{t}(14 ; 18)$ chromosome translocation. Science 226 : 1097-1099, 1984

10) Gavrieli $Y$, Sherman $Y$, Ben-Sasson $S A$ : Identification of programmed cell death in situ via specific labeling of nuclear DNA fragmentation.J Cell Biol 119 : 493-501, 1992

11) 大晹癌研究会編：臨床・病理大腸癌取扱い規約. 改訂第 5 版 . 金原出版, 東京, 1994, p73

12) Knottnerus JA, Leffers $P$ : T he influence of referral patterns on the characteristic of diagnostic tests. J Clin E pidemiol 45 : 1143-1154, 1992

13) Hayflick L, Moorhead PS : T he serial cultivation of human diploid cell stains. Exp Cell Res 25 : 585-621, 1965

14) Imaseki $\mathrm{H}, \mathrm{H}$ ay ashi $\mathrm{H}, \mathrm{T}$ air a $\mathrm{M}$ et al : Expression of c-myc oncogene in colorectal polyps as a biological marker for monitoring malignant potential. Cancer 64 : 704—709, 1989

15) Hainaut $P$, Milner $J$ : Interaction of heat-shock protein 70 with $p 53$ translated in vitro: evidence for interaction with dimeric $p 53$ and for a role in the regulation of $\mathrm{p} 53$ conformation. EMBO J 11 : 3513-3520, 1992

16) A kao $Y$, Otsuki $Y, K$ ataoka $S$ et al : Multiple subcellular localization of bcl-2: detection in nuclear outer membrane, endoplasmic reticulum membrane, and mitochondrial membranes. Cancer Res $54: 2468-2471,1994$

17) Vaux DL, Cory S, A dams JM : Bcl-2 gene promotes haemopoietic cell survival and cooperates with c-myc to immortalize pre-B cells. Nature $335: 440-442,1988$

18) Hockenbery DM, Zutter M, Hickey $W$ et al : BCL 2 protein is topographically restricted in tissues characterized by apoptotic cell death. Proc Natl A cad Sci USA 88 : 6961-6965, 1991

19) Bronner MP, Culin C, Reed JP et al : The bcl-2 proto-oncogene and the gastrointestinal epithelial tumor progression model. A m J Pathol 146 : 2026, 1995

20) A rai T, Kino I: Role of apoptosis in modulation of growth of human colorectal tubular and villous adenomas. J Pathol 176 : 37—44, 1995

21) Koike $M$ : Significance of spontaneous apoptosis during colorectal tumorigenesis. J Surg Oncol 62 : 97-108, 1996

22) Clarke A R, Purdie CA, Harrison DJ et al : Thymocyte apoptosis induced by $\mathrm{p} 53$-dependent and independent pathways. Nature $363: 849-852$, 1993 
23）家田真太郎, 綿谷正弘 : 大腸癌切除後異時性腺腫 発生における p53遺伝子蛋白発現と bcl-2遺伝子蛋 白発現の生物学的役割一初発腺腫との比較か ら一: 日本大腸肛門病会誌 $49:$ 191-198, 1996

\author{
Influence of A poptosis Related Protein for Car cinogenesis of Color ectal \\ A denoma Evaluated by Immunohistochemical Stain \\ Masahiro Katada, Y asuy uki Sugiy ama, Katsuy uki Kunieda and Shigetoy o Saji \\ Second Department of Surgery, Gifu University School of Medicine
}

The expression of mutant $\mathrm{p} 53, \mathrm{bcl}-2$ and the apoptotic index ( $\mathrm{A}$ ) w as investigated by immunohistochemical stain in a total of 174 colorectal tubular adenomas obtained from endoscopic poly pectomy. The following results w ere obtained. T he positive expression of bcl- $2 \mathrm{w}$ as significantly higher in tubular adenoma with moderate aty pia in comparison with mild aty pia, while it slightly decreased in early cancer. The positive expression of mutant p53 increased in proportion to the degree of aty pia of the adenoma and was highest in early cancer. A I value was significantly low er in tubular adenoma with mild sty pia, moder ate aty pia, severe aty pia, early cancer than in normal tissues. The both positive expression of both p53 and bcl-2 were significantly higher in tubular adenomas more than $6 \mathrm{~mm}$ in size and in the shape of I $\mathrm{sp}$ and I $\mathrm{p}$.

1) From the above results, it is suggested that bcl-2 and mutant p53 probably play an important role in the early and late stages of the adenoma-carcinoma sequence. 2) Mor eover, tubular adenomas with more than moder ate aty pia, of more than $6 \mathrm{~mm}$ and pedunculated, should have a high malignant potential.

Reprint requests: Masahiro Katada Second Department of Surgery, Gifu Univer sity School of Medicine 40 T sukasamachi, Gifu, 500-8076 JA PA N 